\title{
Kandungan Nitrat, Fosfat Dan Pertumbuhan Biomassa Basah Kiambang (Salvinia molesta) Di Perairan Danau Buyan, Buleleng, Bali
}

\author{
Ni Wayan Indah Purnamawati a*, I Wayan Arthana a, \\ Suprabadevi Ayumayasari Saraswati ${ }^{a}$ \\ a Program Studi Manajemen Sumberdaya Perairan, Fakultas Kelautan dan Perikanan, Universitas Udayana, Kampus UNUD \\ Jimbaran, Badung, Bali - Indonesia \\ * Penulis koresponden. Tel.: +62-857-043-14982 \\ Alamat e-mail: indahpurnamawati274@yahoo.com
}

Diterima (received) 28 September 2017; disetujui (accepted) 22 Februari 2018; tersedia secara online (available online) 24 Februari 2018

\begin{abstract}
The objective of this research was to determined the relationship between nitrate and phosphate content on the growth of wet biomass Salvinia molesta in Buyan Lake, and also to know the difference of growth of Salvinia molesta in each station with different treatment. The research was conducted from February to March 2017 at Buyan Lake. Biomass measurements and water sampling were carried out at 4 stations with a plot of each treatment. The measurement of wet-biomass were carried out in situ by measuring at each treatment and for measuring the nitrate and phosphate content performed in the laboratory. The result showed that nitrate correlated with biomass growth of Salvinia molesta at the lowest treatment with $R^{2}$ value of 0,105 and the highest at quarter treatment with value $R^{2}$ of 0,889 . The phosphate relationship with the lowest wet biomass growth was at full treatment with the $R^{2}$ value of 0.042 and the highest in the quarter treatment with the $\mathrm{R}^{2}$ value of 0.936 . The highest growth was found in station 1 and the lowest growth at station 4 . For each treatment, the highest growth treatment was in a quarter treatment.
\end{abstract}

Keywords: Buyan lake; kariba weed; nitrate; phosphat

\begin{abstract}
Abstrak
Penelitian ini bertujuan untuk mengetahui hubungan kandungan nitrat dan fosfat terhadap pertumbuhan biomassa basah kiambang di Danau Buyan, serta mengetahui perbedaan pertumbuhan kiambang (Salvinia molesta) di setiap stasiun dengan perlakuan yang berbeda. Penelitian ini dilaksanakan bulan Februari sampai Maret 2017 di Danau Buyan. Pengukuran biomassa dan pengambilan sampel air dilaksanakan di 4 stasiun dengan dibuat petakan masing masing perlakuan. Pengukuran biomassa basah kiambang dilaksanakan insitu dan untuk mengukur kandungan nitrat dan fosfat dilaksanakan di laboratorium. Hasil penelitian menunjukkan hubungan nitrat dengan pertumbuhan biomassa kiambang pada perlakuan setengah paling rendah dengan nilai $\mathrm{R}^{2}$ 0,105 dan paling tinggi pada perlakuan seperempat dengan nilai $\mathrm{R}^{2} 0,889$. Hubungan fosfat dengan pertumbuhan biomassa basah kiambang yang paling rendah pada perlakuan penuh dengan nilai $R^{2} 0,042$ dan yang paling tinggi pada perlakuan seperempat dengan nilai $\mathrm{R}^{2}$ 0,936. Pertumbuhan yang paling tinggi terdapat pada stasiun 1 dan pertumbuhan yang paling rendah pada stasiun 4. Perlakuan yang memiliki pertumbuhan paling tinggi adalah pada perlakuan seperempat
\end{abstract}

Kata Kunci: danau Buyan; kiambang; nitrat; fosfat

\section{Pendahuluan}

Danau merupakan salah satu bentuk ekosistem air tawar yang bersifat menggenang (lentic). Ekosistem ini menempati daerah yang relatif tidak luas pada permukaan bumi dibandingkan dengan habitat laut dan daratan (Effendi, 2003 dalam Manuaba, 2009). Danau Buyan merupakan danau kaldera yang terbentuk dari hasil letusan gunung api dan runtuhan Gunung Beratan dan Buyan 
Purba. Keadaan ini dapat terlihat dari dinding sisi Utara danau yang curam dan membentuk tebing terjal (Dinas PU, 2000 dalam Restu, dkk 2015). Sebagai suatu sumberdaya alam, perairan Danau Buyan mempunyai nilai sangat penting ditinjau dari beberapa fungsinya seperti dari fungsi ekologi, hidrologi serta ekonomi. Kegiatan kegiatan yang ada di sekitar Danau Buyan menyebabkan Danau Buyan tidak terlepas dari pencemaran (Saputra, 2016).

Selain pencemaran, kegiatan - kegiatan yang ada di sekitar kawasan Danau Buyan menyebabkan meningkatnya kadar nitrat dan fosfat dalam badan air Danau Buyan dan akan menyebabkan ledakan tumbuhan air (Chrismadha dkk., 2011). Menurut Purnomo dkk. (2013), keberadaan nitrat yang disertai keberadaan fospat secara berlebih dapat menstimulir pertumbuhan tumbuhan air secara cepat sehingga terjadi ledakan tumbuhan air. Salah satu tumbuhan air yang tumbuh pesat adalah kiambang (Salvinia molesta). Keberadaan kiambang dalam suatu perairan secara tidak langsung mengganggu organisme yang ada di dalam ekosistem perairan tersebut. Maka dari itu penelitian ini perlu dilakukan untuk mendukung pemanfaatan dan pengelolaan sumberdaya perairan setempat. Penelitian ini bertujuan untuk mengetahui hubungan kandungan nitrat dan fospat terhadap pertumbuhan biomassa basah kiambang di Danau Buyan, serta mengetahui perbedaan pertumbuhan kiambang (Salvinia molesta) di setiap stasiun dan setiap perlakuan berbeda.

\section{Metode Penelitian}

\subsection{Waktu dan Lokasi Penelitian}

Penelitian ini dilaksaksanakan pada bulan Januari - Maret 2017 di Danau Buyan, Desa Pancasari, Buleleng (gambar 1). Penelitian ini dilakukan di empat stasiun yang telah ditentukan dengan masing - masing stasiun mewakili daerah daerah yang mendapat pengaruh dari kegiatan manusia.

Tabel 1.

Stasiun Penelitian

\begin{tabular}{cl}
\hline Stasiun & \multicolumn{1}{c}{ Keterangan } \\
\hline Stasiun 1 & Daerah KJA \\
Stasiun 2 & Daerah pemukiman warga \\
Stasiun 3 & Daerah pertanian \\
Stasiun 4 & Daerah hutan \\
\hline
\end{tabular}

\subsection{Alat dan Bahan}

Pada penelitian ini menggunakan alat - alat yaitu : Timbangan digital, jerigen air, GPS, kamera digital, ember, jaring, pipa, alat tagging, alat tulis, meteran, kertas label, dan laptop. Bahan yang digunakan dalam penelitian ini adalah tanaman kiambang (Salvinia molesta) dan sampel air yang diambil di kolom air di setiap stasiun.

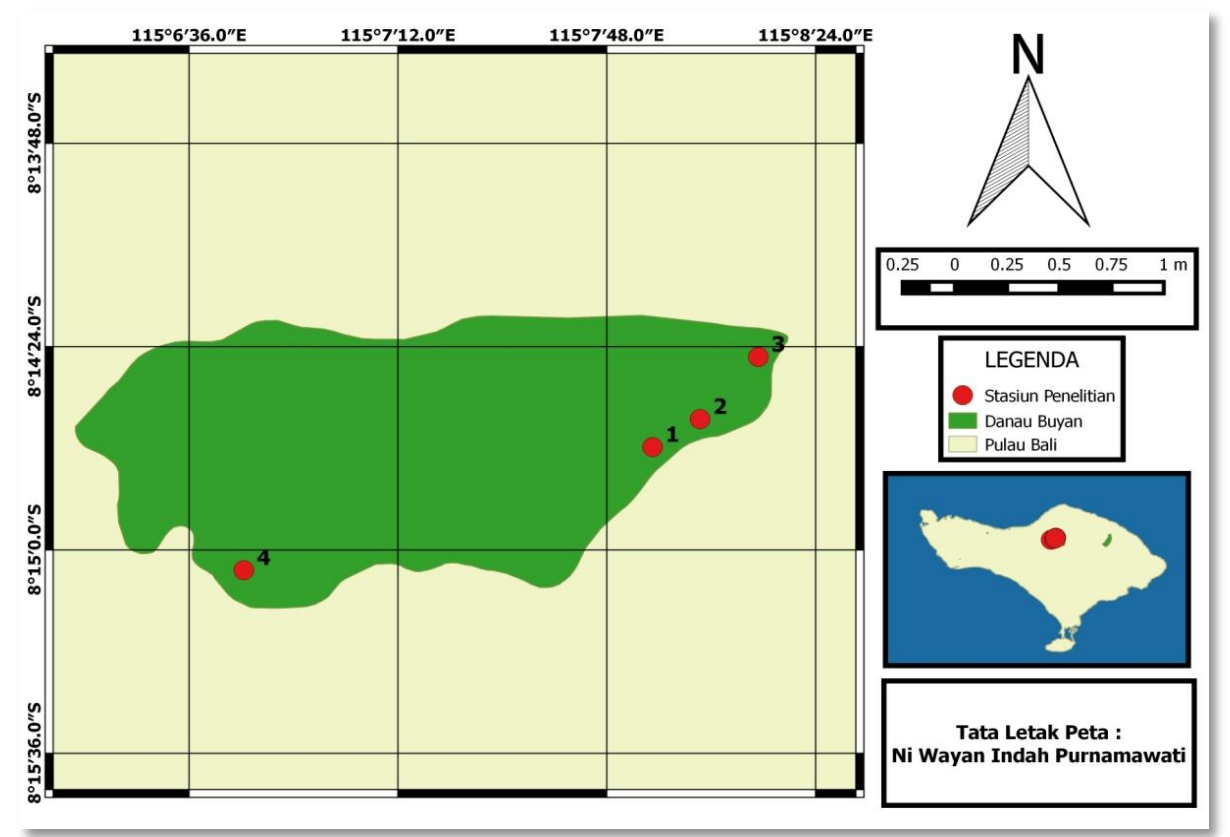

Gambar 1. Peta Lokasi Penelitian 
Tabel 2.

Alat yang digunakan dalam penelitian

\begin{tabular}{|c|c|c|}
\hline No. & Nama Alat & Kegunaan \\
\hline 1. & Timbangan digital & $\begin{array}{l}\text { Digunakan untuk } \\
\text { menimbang kiambang }\end{array}$ \\
\hline 2. & Jerigen air & $\begin{array}{l}\text { Digunakan untuk tempat } \\
\text { sampel air }\end{array}$ \\
\hline 3. & GPS & $\begin{array}{l}\text { Alat yang digunakan untuk } \\
\text { menentukan titik koordinat } \\
\text { lokasi }\end{array}$ \\
\hline 4. & Ember & Digunakan untuk wadah \\
\hline 5. & Jaring & $\begin{array}{l}\text { Digunakan untuk } \\
\text { membatasi kiambang di } \\
\text { setiap stasiun }\end{array}$ \\
\hline 6. & Bambu & $\begin{array}{l}\text { Digunakan untuk } \\
\text { penyangga } 57 \text { arring sebagai } \\
\text { sekat atau pembatas } \\
\text { kiambang }\end{array}$ \\
\hline 7. & Alat tagging & Digunakan untuk menandai \\
\hline 8. & Alat tulis & $\begin{array}{l}\text { Digunakan untuk kegiatan } \\
\text { tulis menulis }\end{array}$ \\
\hline 9. & Meteran & $\begin{array}{l}\text { Untuk mengukur jarak } \\
\text { peletakan sampel }\end{array}$ \\
\hline 10. & Kertas label & $\begin{array}{l}\text { Digunakan untuk memberi } \\
\text { kode pada jerigen air }\end{array}$ \\
\hline 11. & Laptop & $\begin{array}{l}\text { Alat yang digunakan untuk } \\
\text { melihat dan menyimpan } \\
\text { data hasil pengamatan }\end{array}$ \\
\hline
\end{tabular}

Tabel 3.

Bahan yang digunakan dalam penelitian

\begin{tabular}{|c|c|c|}
\hline No. & Nama Bahan & Kegunaan \\
\hline 1. & Sampel Air & $\begin{array}{l}\text { Bahan yang akan diamati } \\
\text { di laboratorium }\end{array}$ \\
\hline 2. & $\begin{array}{l}\text { Tumbuhan } \\
\text { Kiambang }\end{array}$ & $\begin{array}{l}\text { Bahanyang akan } \\
\text { ditimbang berat basahnya }\end{array}$ \\
\hline
\end{tabular}

\subsection{Metode Penelitian}

Penelitian ini menggunakan metode eksperimental dengan pendekatan deskriptif kuantitaf untuk memberikan informasi mengenai hubungan kandungan Nitrat dan Fospat terhadap pertumbuhan biomassa basah Kiambang di Danau Buyan. Penelitian dilakukan pada empat stasiun yang ditetapkan berdasarkan keragaman kondisi lingkungan perairan yang ada.

\subsubsection{Tahapan Penelitian}

Dalam penelitian ini dilaksanakan beberapa tahap, yaitu: (1) Identifikasi, (2) Pengambilan data lapangan, (3) Uji laboratorium.

\section{Identifikasi}

Tahap pertama yang dilakukan dalam penelitian ini adalah identifikasi terhadap permasalahan pertumbuhan kiambang yang sedang terjadi. Mempelajari serta mengkaji pustaka - pustaka yang berkaitan dengan penelitian. Setelah mengidentifikasi permasalahan dilakukan penentuan stasiun stasiun pengamatan. Setiap stasiun mewakili daerah - daerah yang mendapat pengaruh dari kegiatan masyarakat.

\section{Pengambilan Data Lapangan}

a. Pengambilan sampel air dilakukan dengan cara sampel diambil pada setiap stasiun lokasi penelitian yaitu di pertengahan badan airsebanyak 1,5 liter setiap dua minggu sekali. Pengambilan sampel air digunakan untuk pengukuran Nitrat $\left(\mathrm{NO}_{3}\right)$ dan Fosfat $\left(\mathrm{PO}_{4}\right)$. Sampel air kemudian dibawa dan diujikan di Laboratorium Kesehatan Provinsi Bali.

b. Pengukuran biomassa basah dilakukan langsung disetiap stasiun. Di setiap stasiun terdapat tiga perlakuan ruang tumbuh yang berbeda. Di setiap stasiun terdapat 3 petak berukuran $50 \mathrm{~cm}$ x $50 \mathrm{~cm}$ yang berisi kiambang dengan jumlah yang berbeda. Petak pertama berisikan kiambang dengan penuh, petak kedua berisikan setengah, dan petak ketiga berisikan seperempat. Di setiap stasiun terdapat 3 ulangan.

c. Masing - masing petak diukur terlebih dahulu berat dari kiambang. Hal ini dilakukan untuk menentukan berat awal $\left(\mathrm{W}_{0}\right)$ dari kiambang dan sebagai acuan berat awal dari kiambang di setiap stasiunnya.

d. Pengukuran biomassa basah kiambang dilakukan dua minggu sekali bersamaan dengan pengambilan sampel air.

e. Mengacu pada (Pandiangan, 2007), pengukuran biomassa basah kiambang (Salvinia molesta) menggunakan timbangan dengan terlebih dahulu ditaruh pada kertas koran selama lima menit sebelum ditimbang agar air dalam akar kiambang dapat diserap.

3. Pengambilan Data Lapangan

Uji Nitrat $\left(\mathrm{NO}_{3}\right)$ dan Fosfat $\left(\mathrm{PO}_{4}\right)$ sampel air Danau Buyan dilakukan di laboratorium kesehatan Provinsi Bali. pengujian nitrat di UPT Laboratorium Kesehatan Provinsi Bali menggunakan metode Brucine. Pengujian fosfat $\left(\mathrm{PO}_{4}\right)$ menggunakan metode Amm-Molybdat. 


\subsection{Analisis Data}

Analisis parameter pertumbuhan Kiambang (Salvinia molesta) dihitung dengan menentukan besarnya laju pertumbuhan spesifik atau specific growth rate (SGR) (Asmawi, 1983), dan untuk parameter Nitrat $\left(\mathrm{NO}_{3}\right)$ dan Fosfat $\left(\mathrm{PO}_{4}\right)$ diuji di Laboratorium Kesehatan Daerah Provinsi Bali. Persamaan adalah :

$0 \% \frac{W_{t}}{\text { hari }}=\frac{L n W_{t}-L n W_{0}}{t} \times 100 \%$

dimana \%Wt/hari adalah Laju Pertumbuhan Spesifik (\%); Wo adalah Berat basah awal (Kg); Wt adalah Berat Basah akhir $(\mathrm{Kg})$; $\mathrm{t}$ adalah waktu lokasi n (7 hari).

\subsubsection{Analisis Korelasi}

Untuk mengetahui hubungan kandungan Nitrat dan Fosfat terhadap pertumbuhan biomassa basah kiambang (Salvinia molesta) dianalisis menggunakan analisis korelasi dengan microsoft excel.

\section{Hasil dan Pembahasan}

\subsection{Pertumbuhan Kiambang}

Pertumbuhan biomassa kiambang di stasiun 1 mengalami peningkatan tinggi dibandingkan

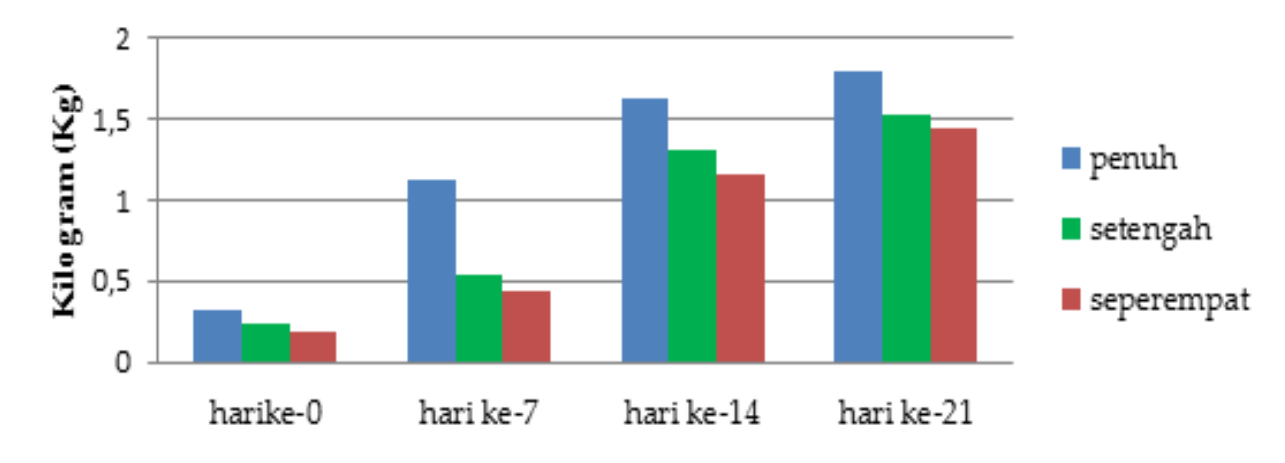

Gambar 2. Berat Kiambang Pada Stasiun 1

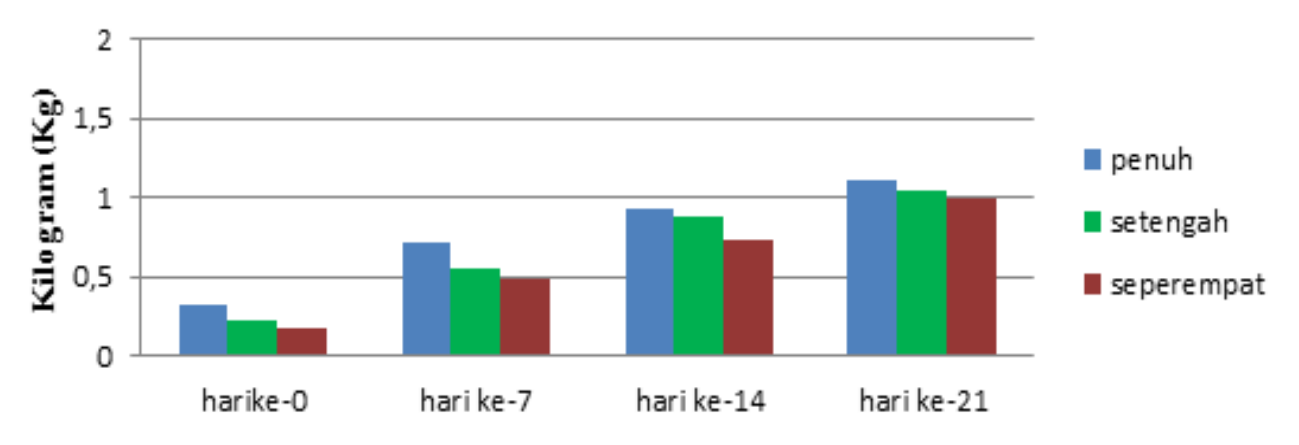

Gambar 3. Berat Kiambang pada Stasiun 2

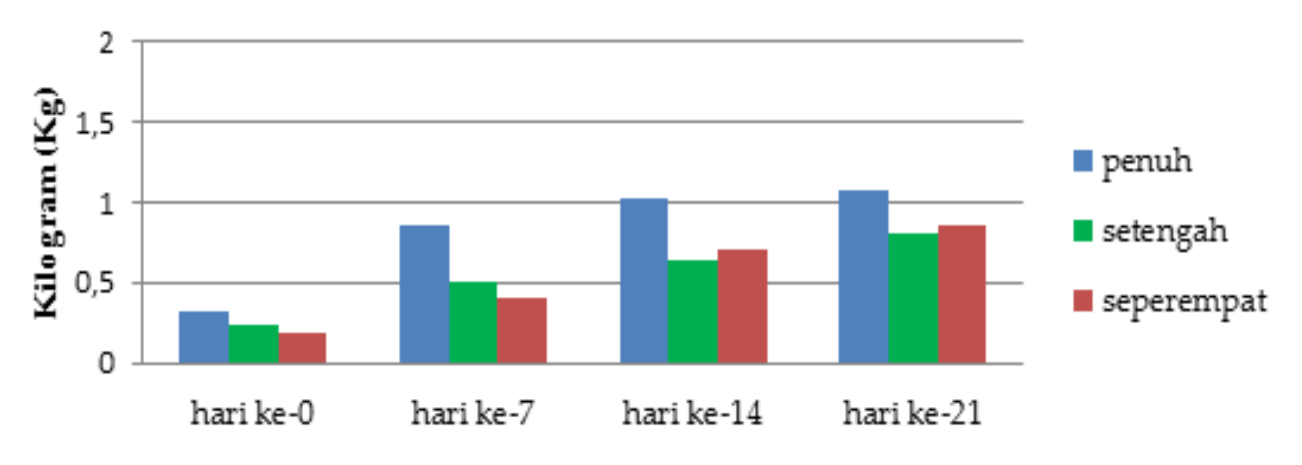

Gambar 4. Berat Kiambang Pada Stasiun 3 


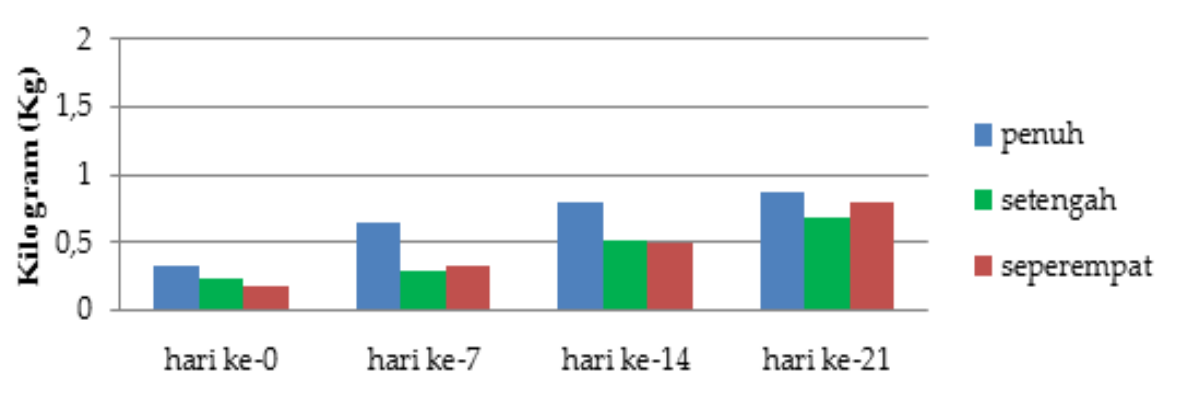

Gambar 5. Berat Kiambang Pada Stasiun 4

dengan ketiga stasiun lainnya (Gambar 2). Pada perlakuan penuh mengalami peningkatan sebesar $459 \%$. Pada perlakuan setengah mengalami peningkatan $560 \%$ dari hari ke - 0 hingga hari ke 21 dan pada perlakuan seperempat mengalami peningkatan $700 \%$. Hal ini dikarenakan pada stasiun 1 merupakan daerah keramba jaring apung (KJA). Kiambang (Salvinia molesta) menyerap unsur hara yang berasal dari KJA di perairan untuk pertumbuhan. Menurut Hutabarat (2000), sumber limbah organik yang berasal dari kegiatan budidaya sistem KJA.

Menurut Prayuda (2016), tumbuhan eceng gondok di Danau Batur mengalami peningkatan biomassa yang tinggi pada daerah KJA. Peningkatan pertumbuhan biomassa kedua setelah stasiun 1 adalah stasiun 2. Pada perlakuan penuh pertumbuhan kiambang dari hari ke -0 hingga hari ke - 21 mengalami peningkatan 245\%. Pada perlakuan setengah mengalami peningkatan sebesar $356 \%$, dan pada perlakuan seperempat mengalami peningkatan sebesar $455 \%$. Pada stasiun 2 masukan limbah perairan berasal dari limbah buangan rumah tangga atau pemukiman masyarakat. Menurut Suhartono (2009), limbah domestik berasal dari deterjen, sabun, minyak, dan lemak. Limbah domestik yang masuk kedalam perairan secara terus menerus dapat menyebabkan eutrofikasi.

Peningkatan pertumbuhan biomassa kiambang ketiga adalah di stasiun 3. Stasiun 3 ini merupakan daerah pertanian masyarakat. Pertanian di tepian danau buyan ini biasa nya menggunakan pupuk dan pestisida. Pada perlakuan penuh di stasiun 3 terjadi peningkatan sebesar $0,76 \mathrm{~kg}$ yaitu sebesar $237 \%$ dari hari ke - 0 hingga hari ke - 21, pada perlakuan setengah mengalami peningkatan sebesar $0,58 \mathrm{~kg}$ atau $252 \%$, dan pada perlakuan seperempat mengalami peningkatan sebesar 0,68 $\mathrm{kg}$ yaitu sebesar 378\%. Masukan limbah pada stasiun 3 berasal dari kegiatan pertanian yang ada di tepian danau buyan. Masukan limbah pertanian berasal dari pupuk dan pestisida yang digunakan oleh petani. Salim (2002) mendapatkan bahwa pupuk akan terserap oleh tanaman hanya $15 \%$ dari aplikasi, sisanya akan terikat oleh tanah. Pada saat hujan pupuk tersebut akan larut dan terbawa bersamaan dengan partikel tanah menuju perairan.

Peningkatan pertumbuhan biomassa kiambang terendah yaitu di stasiun 4. Pada stasiun 4 perlakuan penuh biomassa di hari ke 21 hanya mencapai 0,88 gram yang artinya dari berat awal 0,32 gram hanya mengalami peningkatan sebesar $175 \%$ yaitu 0,56 gram. Pada perlakuan setengah mengalami peningkatan sebesar $200 \%$ atau 0,46 gram. Pada perlakuan seperempat mengalami peningkatan sebesar $317 \%$ dalam gram sebesar 0,57 gram. Hal ini dikarenakan pada stasiun 4 tidak ada kegiatan yang dapat menghasilkan limbah bagi perairan. Pada stasiun 4 merupakan daerah yang jauh dari kegiatan masyarakat dan juga pada stasiun 4 ini dekat dengan daerah hutan.

\subsection{SGR Kiambang}

SGR pada perlakuan penuh di setiap stasiun memiliki pola yang sama. SGR mengalami peningkatan dari hari ke - 0 sampai hari ke -7 dan kemudian mengalami penurunan dari hari ke -14 sampai hari ke - 21. Pada hari ke - 7 dan hari ke 14 SGR tertinggi terdapat pada stasiun 1 dan pada hari ke - 21 SGR tertinggi terdapat pada stasiun 2.

Pada Gambar 7 terlihat pada perlakuan setengah pola SGR di setiap stasiun juga mengalami penurunan di hari ke - 14 sampai hari ke - 21, hanya pada stasiun 1 mengalami peningkatan di hari ke - 14. Pada perlakuan setengah SGR tertinggi pada hari ke -7 terdapat pada stasiun 2, dihari ke - 14 SGR tertinggi 
terdapat pada stasiun 1 dan SGR tertinggi pada hari ke - 21 terdapat pada stasiun 4 .

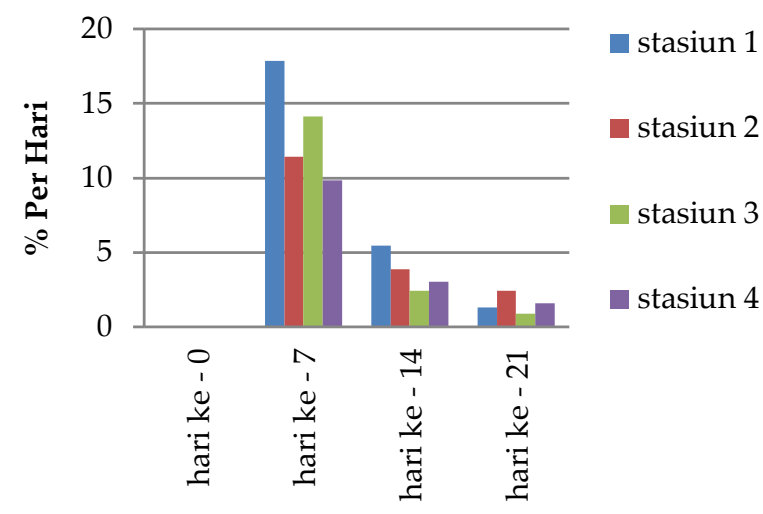

Gambar 6. SGR Kiambang Pada Perlakuan Penuh

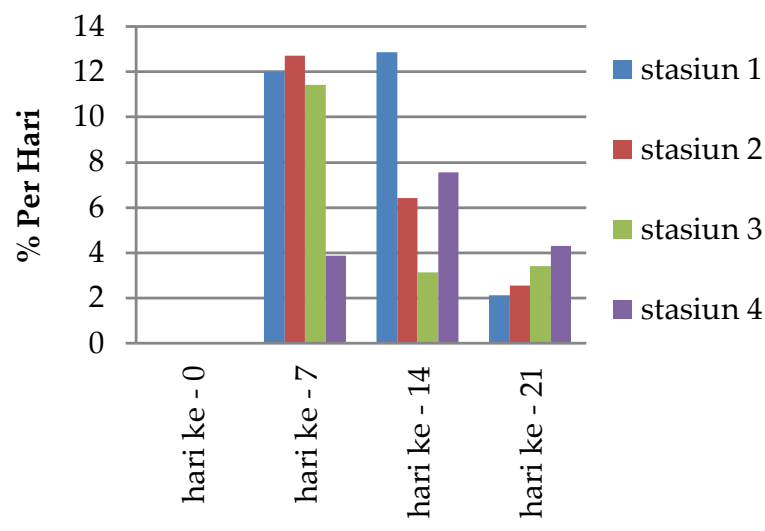

Gambar 7. SGR Kiambang Pada Perlakuan Setengah

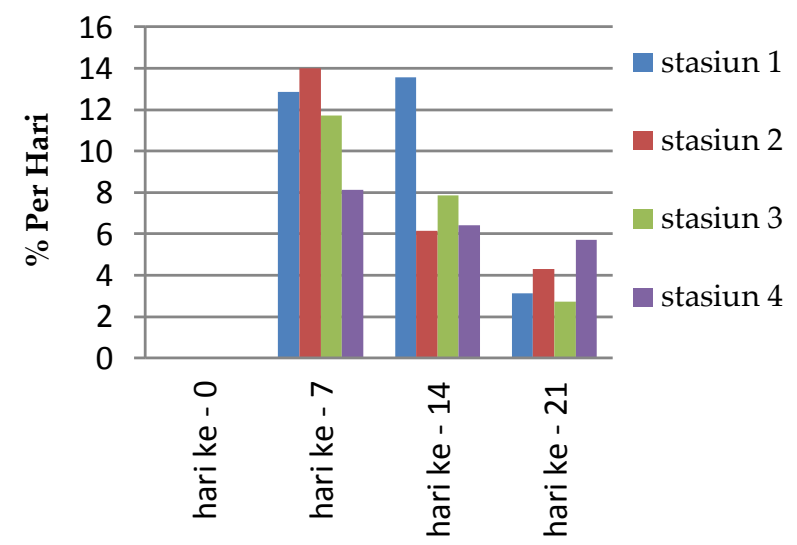

Gambar 8. SGR Kiambang Pada Perlakuan Seperempat

SGR kiambang pada perlakuan seperempat memiliki pola yang dengan perlakuan setengah. SGR tertinggi pada perlakuan seperempat di hari ke -7 terdapat pada stasiun 2, di hari ke - 14 SGR tertinggi terdapat pada stasiun 1 dan di hari ke 21 SGR tertinggi terdapat pada stasiun 4. Dari ketiga perlakuan pada perlakuan penuh penurunan SGR terjadi secara signifikaan. Penurun ini terjadi dari minggu ke -14 sampai minggu ke-21. Penurunan yang signifikan itu diduga karena pengaruh ruang untuk tumbuh bagi kiambang. Tumbuhan kiambang akan berkembang pesat apabila mendapat ruang tumbuh yang luas. Yuliani dkk. (2013), menyatakan bahwa pertumbuhan tanaman kiambang dipengaruhi oleh ruang tumbuh, makin sempit ruang tumbuhnya maka pertumbuhannya akan makin lambat dan sebaliknya. Selain pengaruh ruang pertumbuhan, hal ini juga di pengaruhi oleh faktor umur dari tumbuhan. Tumbuhan kiambang mengalami pertumbuhan yang cepat 7 sampai 14 hari, setelah itu tanaman sudah tua pertumbuhan tanaman akan semakin lama. Hal ini sesuai dengan pernyataan (Pribadi dkk., 2016) kiambang yang sudah tua lambat menyerap unsur hara di perairan.

\subsection{Nitrat dan Fospat di Peraiaran}

Kandungan nitrat dan fospat di setiap stasiun mengalami peningkatan dan penurunan. Pada hari ke - 21 rata - rata disetiap stasiun kadar nitrat dan fospat mengalami penurunan. Hal ini dikarenakan nitrat dan fospat di perairan telah diserap oleh kiambang untuk pertumbuhan. Dari hasil pengukuran yang dilakukan di 4 stasiun setiap satu minggu sekali, kandungan nitrat terendah adalah 0,086 dan kandungan nitrat tertinggi adalah 4, $89 \mathrm{mg} / \mathrm{l}$. Hasil kandungan nitrat ini bila dibandingkan dengan standar baku mutu air Peraturan Gubernur Nomor 16 Tahun 2016 (kelas III), masih sangat jauh dari batas yang ditentukan yaitu 20 mg/l. Namun, Tatangindatu dkk., (2013) menyatakan kadar nitrat yang lebih dari $5 \mathrm{mg} / \mathrm{l}$ menggambarkan telah terjadinya pencemaran.

Tabel 4.

Hasil Nitrat dan fosfat

\begin{tabular}{cccccc}
\hline \multirow{2}{*}{$\begin{array}{c}\text { Stasiun } \\
\text { penelitian }\end{array}$} & \multirow{2}{*}{ Parameter } & \multicolumn{4}{c}{ Pengambilan sampel hari ke } \\
\cline { 2 - 6 } & & 0 & 7 & 14 & 21 \\
\hline \multirow{2}{*}{ St 1 } & Nitrat & 1,703 & 1,645 & 4,890 & 1,205 \\
\cline { 2 - 6 } & fospat & 0,132 & 0,105 & 12,195 & 2,262 \\
\hline \multirow{2}{*}{ St 2 } & Nitrat & 0,098 & 0,145 & 0,220 & 0,225 \\
\cline { 2 - 6 } & fospat & 0,154 & 0,104 & 0,316 & 0,365 \\
\hline \multirow{2}{*}{ St 3 } & Nitrat & 1,641 & 2,672 & 0,534 & 0,742 \\
\cline { 2 - 6 } & fospat & 0,100 & 0,010 & 0,048 & 0,032 \\
\hline \multirow{2}{*}{ St 4 } & Nitrat & 0,086 & 1,771 & 0,144 & 0,123 \\
\cline { 2 - 6 } & fospat & 0,023 & 0,010 & 0,159 & 0,057 \\
\hline
\end{tabular}



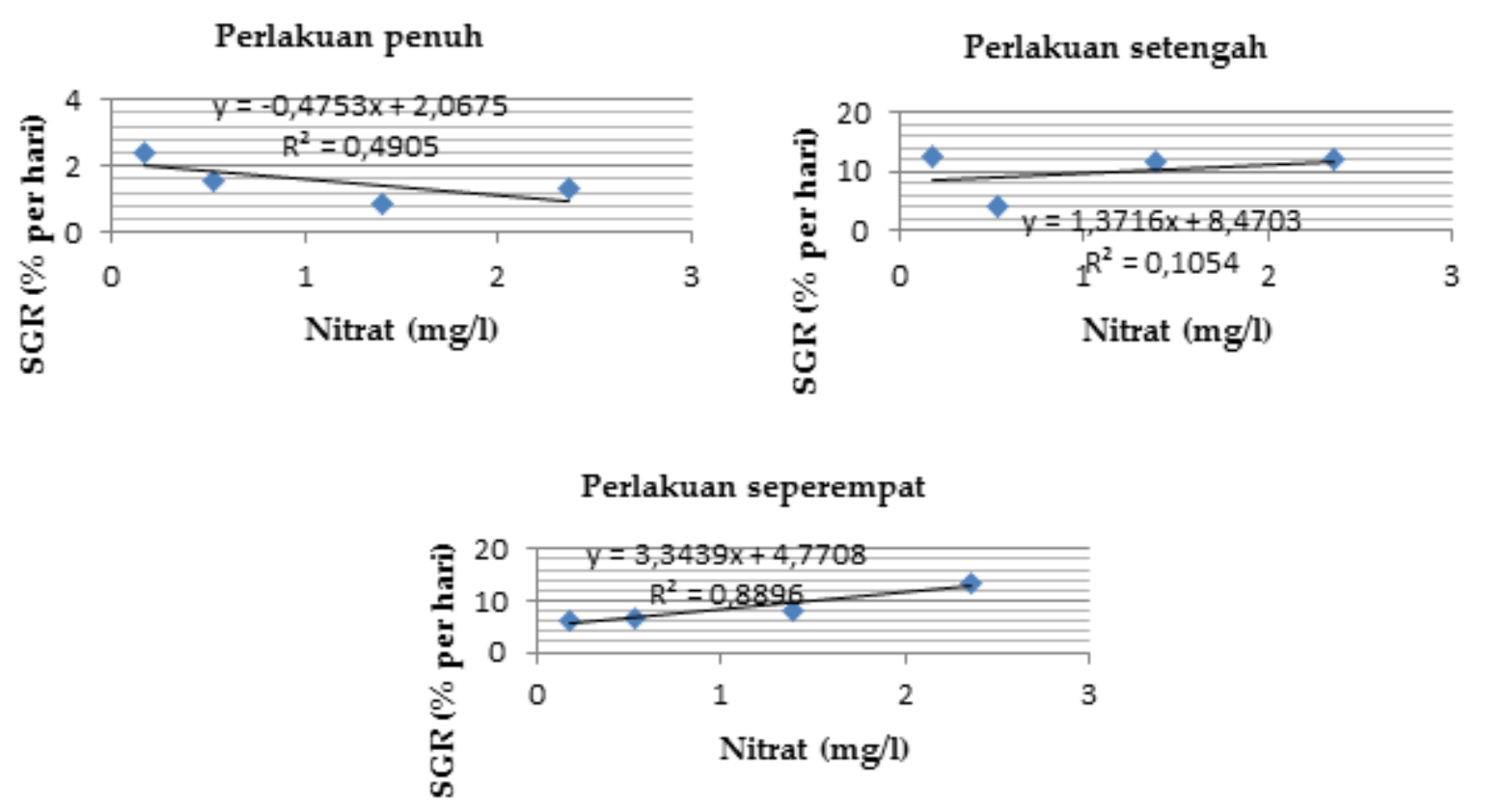

Gambar 9. Hubungan Nitrat dengan Pertumbuhan Kiambang di Setiap perlakuan

Sedangkan kandungan fospat di di keempat stasiun penelitian nilai tertinggi adalah 12,195 mg/l pada stasiun 1 yang merupakan daerah budidaya ikan, dan yang terendah adalah $0,0100 \mathrm{mg} / \mathrm{l}$ pada stasiun 4 yang merupakan daerah dekat hutan dan tidak terdapat aktivitas manusia. Hasil kandungan fospat ini telah melebihi ambang batas baku mutu lingkungan yang ditetapkan dalam baku mutu air Peraturan Gubernur Nomor 16 Tahun 2016 (kelas III) yaitu sebesar 1 mg/l. Dari hasil tersebut perairan danau buyan telah mengalami pencemaran. Nilai fospat paling tinggi perminggunya terdapat distasiun 1 , hal ini disebabkan di stasiun satu merupakan daerah budidaya ikan. Sesuai dengan pernyataan (Tatangindatu dkk., 2013), Fospat yang disumbangkan ke dalam perairan berasal dari kegiatan budidaya yaitu sisa pakan pellet dari ikan yang terbuang di dalam perairan.

\subsection{Hubungan Nitrat dan Fospat Terhadap Pertumbuhan Kiambang}

Dari hasil analisis korelasi pada (Gambar 9), penilitian ini menunjukan adanya hubungan antara kandungan nitrat dengan pertumbuhan kiambang. Jika nilai $r$ semakin mendekati 1 berarti hubungan antara dua variabel semakin kuat dan sebaliknya nilai mendekati 0 hubungan antara dua variabel semakin lemah. Pada penelitian ini hubungan nitrat dengan pertumbuhan kiambang pada perlakuan setengah tidak terdapat hubungan dan yang menyatakan adanya hubungan antara kandungan nitrat dengan pertumbuhan kiambang pada perlakuan seperempat. Hasil ini menunjukan di alam kandungan nitrat sangat mempengaruhi pertumbuhan kiambang yaitu sebesar $88 \%$. Pada Gambar 9 dapat dilihat untuk perlakuan penuh nilai $R^{2}$ 0,490, dengan nilai regresi negatif yang artinya hubungan nitrat dengan pertumbuhan kiambang berbanding terbalik. Pada perlakuan penuh semakin tinggi nilai nitrat semakin rendah pertumbuhan kiambang. Pada perlakuan setengah nilai $R^{2} 0,105$, pada perlakuan seperempat nilai $R^{2}$ 0,889 . Pada perlakuan seperempat nitrat dan pertumbuhan kiambang memiliki nilai positif atau berbanding lurus.

Hubungan kandungan fospat dengan pertumbuhan kiambang (Gambar 10) memiliki persamaan dengan hubungan kandungan nitrat dengan pertumbuhan kiambang. Hubungan fospat dengan pertumbuhan kiambang pada perlakuan penuh memiliki nilai paling rendah dan paling tinggi pada perlakuan seperempat. Hubungan fospat dengan pertumbuhan kiambang pada perlakuan penuh memiliki nilai $\mathrm{R}^{2}$ 0,046, pada perlakuan setengah nilai $R^{2} 0,120$, dan pada perlakuan seperempat nilai $\mathrm{R}^{2} 0,936$. Kandungan fospat di alam mempengaruhi pertumbuhan kiambang jika ruang tumbuh yang luas. Dari 

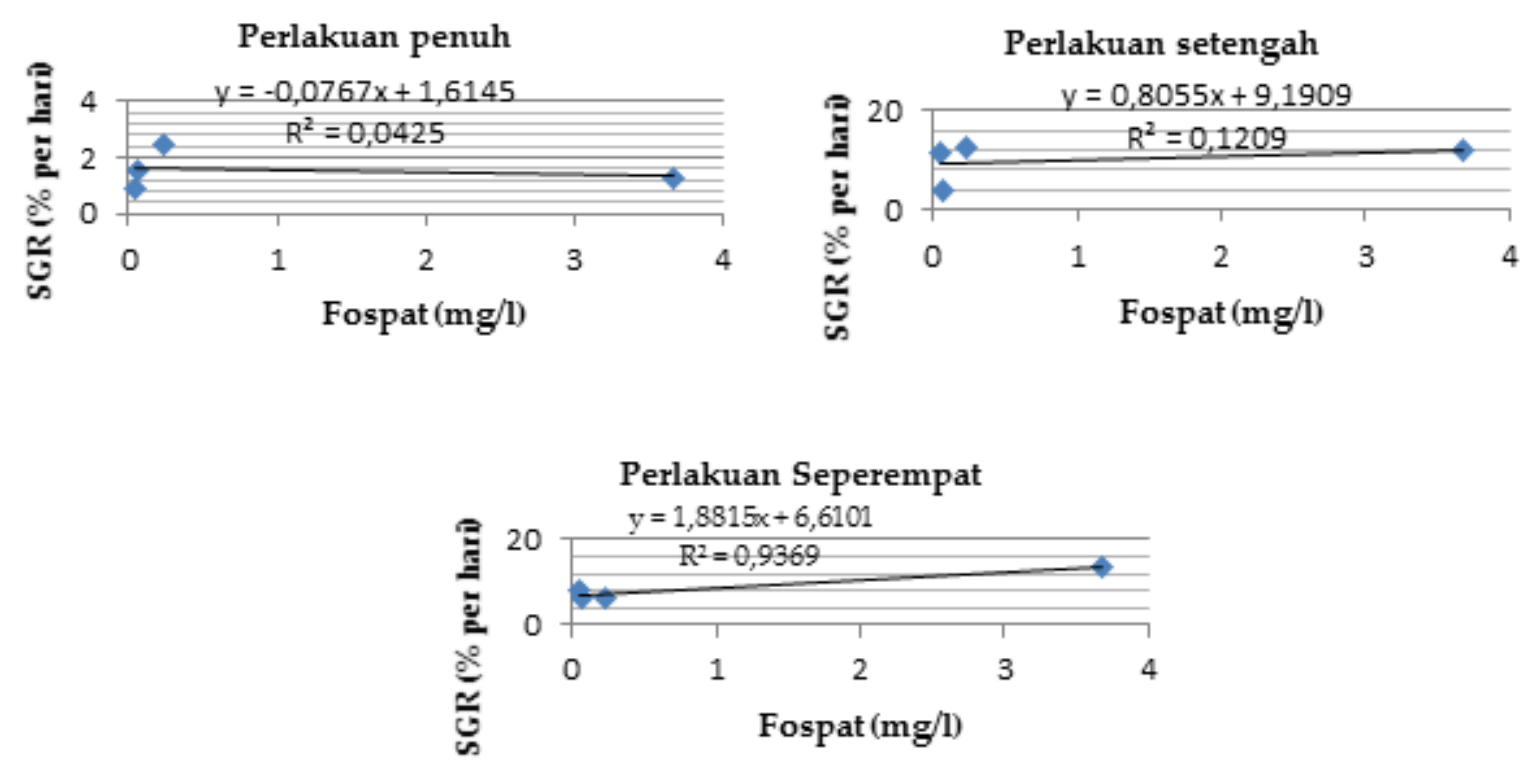

Gambar 10. Hubungan Fospat dengan Pertumbuhan Kiambang Pada Setiap Perlakuan

analisis korelasi variabel nitrat dan fospat memberikan pengaruh langsung terhadap pertumbuhan kiambang. Nilai $\mathrm{R}^{2}$ yang paling mendekati 1 yaitu pada perlakuan seperempat.

Hal ini disebabkan karena pertumbuhan kiambang dipengaruhi oleh luasan area pertumbuhannya. Sesuai dengan pernyataan dari (Yuliani dkk., 2013), yang menyatakan bahwa pertumbuhan tanaman kiambang dipengaruhi oleh ruang tumbuh, makin sempit ruang tumbuhnya maka pertumbuhannya akan makin lambat dan sebaliknya. Hal ini berkaitan dengan perebutan penyerapan unsur hara untuk pertumbuhan kiambang. Menurut Bornette and Piujalon, (2011), unsur nitrogen merupakan unsur hara (nutrien) yang diperlukan oleh tumbuhan untuk pertumbuhan dan perkembangan hidup tumbuhan air. Pada perlakuan seperempat pertumbuhan kiambang sangat cepat karena jumlah kiambang lebih sedikit sehingga tumbuhan kiambang lebih banyak dapat menyerap unsur hara. Menurut Christanty dkk., (2016), kandungan nitrat dan fospat di perairan Rawa Kongsi memberikan pengaruh yang nyata terhadap pertumbuhan eceng gondok. Dapat dilihat dari hasil penelitian ini kiambang ( Salvinia molesta) menyerap unsur hara dengan cepat, hal ini memberikan dampak positif bagi ekosistem Danau Buyan karena dapat meminimalisir terjadinya pencemaran di Danau Buyan.
Selain cepat menyerap unsur hara, (Pavithra dan Kousar, 2016), menyatakan kiambang (Salvinia molesta) juga dapat menyerap atau menghilangkan sejumlah besar nutrisi dari limbah tekstil. Hasil penelitian dari (Oktavia dkk., 2016) menunjukan tanaman kiambang (Salvinia molesta) dapat menurunkan kadar kadmium ( $\mathrm{Cd}$ ) pada air limbah home industry batik. Pengangkutan berlangsung dari akar menuju bagian atas tumbuhan melalui berkas pembuluh, yaitu xylem (Norhidayah dkk., 2014). Hal ini juga dapat memberi dampak negatif bagi ekosistem Danau Buyan. Dampak negatif yang dapat ditimbulkan yaitu terganggu kehidupan biota yang dihidup dibawah tanaman kiambang, karena kiambang bersifat mengapung di permukaan air dan dengan cepat dapat berkembang.

\section{Simpulan}

Kandungan nitrat memberi pengaruh terhadap pertumbuhan biomassa kiambang pada perlakuan seperempat dengan nilai $\mathrm{R}^{2}$ 0,889. kandungan fospat memberi pengaruh terhadap pertumbuhan biomassa basah kiambang pada perlakuan seperempat dengan nilai $\mathrm{R}^{2}$ 0,936.

Pertumbuhan kiambang yang paling tinggi terdapat pada stasiun 1 yang merupakan daerah dekat dengan KJA dan pertumbuhan yang paling rendah pada stasiun 4 yang berada dekat dengan hutan. Perlakuan yang memiliki pertumbuhan paling tinggi adalah pada perlakuan seperempat. 


\section{Daftar Pustaka}

Bornette, G., \& Puijalon, S. (2011). Response of aquatic plants to abiotic factors: a review. Aquatic Sciences, 73(1), 1-14.

Chrismada, T., Haryani, G. S., Fakhrudin, M., \& Hehanussa, P. E. (2011). Aplikasi ekohidrologi dalam pengelolaan danau. Dalam Prosiding Seminar Nasional Ekohidrologi. Jakarta, Indonesia, 24 Maret 2011 (pp. $25-24)$.

Christanty, Y., Barus, T. A., \& Desrita, D. (2016). Hubungan Kandungan Nitrat dan Fospat Terhadap Pertumbuhan Biomassa Basah Eceng Gondok Di Rawa Kongsi Sumatera Utara. Jurnal Aquacastmarine, 13(3), 155-166.

Manuaba, I. B. P. (2009). Cemaran Pestisida Karbamat dalam Air Danau Buyan Buleleng, Bali. Jurnal Kimia, 3(1), 48-54.

Norhidayah, N., Sofarini, D., \& Yunandar, Y. (2016). Fitoremediasi Tumbuhan Air Kiambang (Salvinia molesta) Purun Tikus (Eleocharis dulcis) dan Perupuk (Phragmites karka) Sebagai Alternatif Pengolahan Limbah Cair Karet. EnviroScienteae, 10(1), 18-26.

Oktavia, Z., Budiyono, B., \& Dewanti, N. A. Y. (2016). Pengaruh Variasi Lama Kontak Fitoremediasi Tanaman Kiambang (Salvinia Molesta) Terhadap Kadar Kadmium (Cd) Pada Limbah Cair Home Industry Batik " $\mathrm{X}$ " Magelang. Jurnal Kesehatan Masyarakat (e-Journal), 4(5), 238-245.

Pandiangan, E. J. (2007). Pengaruh Kualitas Air Terhadap Pertumbuhan Eichhornia crassipes (Mart.) Solms. Bogor, Indonesia: Institut Pertanian Bogor.

Pavithra, M., \& Kousar, H. (2016). Potential of Salvinia molesta for Removal of Sodium in Textile Wastewater. Journal of Bioremediation and biodegradation, 7(5), 1000364.

Prayuda, L. R., Arthana, I. W., \& Dewi, A. P. W. K. (2017). Pengaruh Nitrat (NO3) Terhadap
Pertumbuhan Alami Eceng Gondok (Eichornia crassipes Solms.) Berdasarkan Biomassa Basah Di Danau Batur, Kintamani, Bali. Journal Of Marine And Aquatic Sciences, 3(2), 215-222.

Pribadi, R. N., Zaman, B., \& Purwono, P. (2016). Pengaruh Luas Penutupan Kiambang (Salvinia molesta) Terhadap Penurunan COD, Amonia, Nitrit, dan Nitrat Pada Limbah Cair Domestik (Grey Water) Dengan Sistem Kontinyu. Jurnal Teknik Lingkungan, 5(4), 1-10.

Purnomo, P. W., Nitisupardjo, M., \& Purwandari, Y. (2013). Hubungan Antara Total Bakteri Dengan Bahan Organik, $\mathrm{NO}_{3}$ Dan $\mathrm{H}_{2} \mathrm{~S}$ Pada Lokasi Sekitar Eceng Gondok Dan Perairan Terbuka Di Rawa Pening. Management of Aquatic Resources Journal, 2(3), 85-92.

Restu I. W., Kartika, G. R. A., \& Pratiwi, M. A. (2015). Kajian potensi sumberdaya hayati dan kualitas sebagai indokator kualitas lingkungan Danau Buyan dan Tamblingan. Dalam Seminar Nasional Sains dan Teknologi (SENASTEK-2015). Bali, Indonesia, 29-30 Oktober 2015.

Salim, H. (2002). Beban pencemaran limbah domestic dan pertanian di DAS Citarum hulu. Jurnal Teknlogi Lingkungan, 3(2), 107-111.

Saputra, I. W. R. R., Restu, I. W., \& Pratiwi, M. A. (2016). Analisis kualitas air danau sebagai dasar perbaikan manajemen budidaya perikanan Danau Buyan Kabupaten Buleleng, Provinsi Bali. ECOTROPHIC: Journal of Environmental Science, 11(1), 1-7.

Tatangindatu, F., Kalesaran, O., \& Rompas, R. (2013). Studi parameter fisika kimia air pada areal budidaya ikan di Danau Tondano, Desa Paleloan, Kabupaten Minahasa. E-Journal Budidaya Perairan, 1(2), 8-19.

Yuliani, D. E., Sitorus, S., \& Wirawan, T. (2016). Analisis kemampuan kiambang (Salvinia molesta) untuk menurunkan konsentrasi ion logam Cu (II) pada media tumbuh air. Jurnal Kimia Mulawarman, 10(2), 68-73.

(C) 2018 by the authors; licensee Udayana University, Indonesia. This article is an open access article distributed under the terms and conditions of the Creative Commons Attribution license (http://creativecommons.org/licenses/by/3.0/). 